\title{
Welfare States and Social Europe
}

Martinsen, Dorte Sindbjerg

Published in:

Social Services of General Interest in the EU

Publication date:

2013

Document version

Early version, also known as pre-print

Citation for published version (APA):

Martinsen, D. S. (2013). Welfare States and Social Europe. In U. Neergaard, E. Szyszczak, J. W. van de Gronden, \& M. Krajewski (Eds.), Social Services of General Interest in the EU (pp. 53-73). TMC Asser Press.

Legal Issues of Services of General Interest 


\title{
Chapter 3
}

\section{Welfare States and Social Europe}

Dorte Sindbjerg Martinsen*

In Szyszczak, E., Neergaard, U., Krajewski, M., Gronden, J.W. van de and Bastiaans, M. (eds.) (2013) Social Services of General Interest in the EU. TMC Asser Press and Springer.

\begin{abstract}
The chapter examines the tensions between welfare states on the one hand and social Europe on the other and colliding principles in their historical setting. In particular, the chapter focuses on Social Services of General Interest (SSGI) as core institutions of the welfare state and the political response to the European impact on these public services, looking in particular at health care and long term care. The findings point out that that although Member States attempt to create 'safe havens' to protect their welfare policies from European law, these may not prove to be lasting firewalls against the 'creeping competences' of the European Union. Over time SSGI have become Europeanized, limiting the scope and policy options for national politicians and national administrations. Also the administrative space of SSGI is increasingly multi-level, forcing administrators at all levels to take EU rules into account, when welfare programs are designed, adopted and administered.
\end{abstract}

\section{Contents}

3.1 Introduction.

3.2 Social Europe.

${ }^{*}$ Dorte S. Martinsen

Associate Professor, PhD

Department of Political Science, University of Copenhagen, Øster Farimagsgade 5, 1353 Copenhagen

K., Denmark

e-mail: dm@ifs.ku.dk 
3.3 Social Services of General Interest

3.3.1 Health care

3.3.2 Long term care

3.4 The Europeanization of welfare

3.5 Conclusions

\subsection{Introduction}

The competence to decide on the content, scope and organization of welfare policies remains within national competence in the European Union (EU) as long as the exercise of that competence does not contradict EU law. The trick is to balance 'welfare sovereignty' and EU law; this constitutes a central dilemma for contemporary welfare states in the European Union. The dilemma has only intensified over the years.

Historically, the welfare state construction has been closely linked to the formation and consolidation of the nation-state. ${ }^{1}$ The demarcation of the nation, and the territorial borders, of the state has traditionally defined social citizenship, i.e. who, when and where to be protected against social risks. In its gradual development, welfare came to constitute a decisive means of national integration, where material rights and obligations linked the state and civil society together. Generally, the modern welfare has been proposed, created and developed for the nation, historically aiming at national integration and coherence:

... the welfare state has always been a national state and this connection is far from coincidental. One of the main factors impelling the development of welfare systems has been the desire on the part of governing authorities to promote national solidarity. From early days to late on, welfare systems were constructed as part of a more generalized process of state building. Who says welfare state says nationstate. $^{2}$

From a formal point of view, Member States of the EU still possess social sovereignty. Despite a generally intensified process of European integration, social policies have long appeared as a

\footnotetext{
${ }^{1}$ Eichenhofer 1999a; 2000; Ferrera 2003.

${ }^{2}$ Giddens 1994, pp. 136-137.
} 
remaining stronghold of the sovereign nation-state against the influence of EU law and policy - 'an island beyond its reach'. ${ }^{3}$

The historical meaning of the welfare state in part explains why European integration of welfare is ripe with tensions, contradictions and reluctance, since it challenges the original national embeddedness of welfare. From a historical point of view, welfare states and social Europe contradict one another. National welfare states are underpinned by a logic of 'closure' whereas the EU is guided by a logic of 'opening'. ${ }^{4}$ Whether the tensions between those two logics can somehow meet and reconcile in future social Europe remains to be seen.

This chapter focuses on the tensions between welfare states on the one hand and social Europe on the other, but also on how the two entities have gradually been brought together, albeit sometimes in an incoherent and conflicting manner. In particular, the chapter focuses on Social Services of General Interest (SSGI) as core institutions of the welfare state and the political response to the European impact on these public services. Section two below examines Social Europe, its scope and content. Section three turns to two specific welfare provisions, defined as social services of general interest; health care and long term care and examines the political response to their European integration. Section four analyzes the Europeanization of welfare. Finally, some concluding remarks are provided.

\subsection{Social Europe}

The existence and reach of social Europe has long been debated. Formally regarded, the organization of welfare continues to be a national prerogative, and 'social Europe' has been laid down as 'the road not taken'. 5 Member States have acted as very skeptical gatekeepers when welfare initiatives have had to be approved in the Council of Ministers, in this way forcefully protecting their prerogatives. ${ }^{6}$ Throughout the decades of European integration, welfare policies

\footnotetext{
${ }^{3}$ As formulated by Advocate General Tesauro in ECJ, Case C-120/95 Decker [1998] ECR I-01831 and ECJ, Case C-158/96 Kohll [1998] ECR I-01931; Eichenhofer 1999b, p. 102.

${ }^{4}$ Ferrera 2005; 2009.

${ }^{5}$ Von Maydell 1999, p. 9; Scharpf 2002, p. 645.

${ }^{6}$ Leibfried 2010, p. 257.
} 
have continued as one of the few policy areas where national governments have usually 'resisted losses of political authority, not least because of the electoral significance of most social programs. ${ }^{, 7}$ An apparent lasting asymmetry has thus been created:

...the course of European integration from the 1950s onward has created a fundamental asymmetry between policies promoting market efficiencies and those promoting social protection and equality. ${ }^{8}$

Ideas and initiatives on social Europe have thus not been received lightheartedly by welfare state representatives. In its content and scope, social Europe contains different dynamics and meanings, being pushed forward by some binding laws adopted in the Council, by means of judicial policymaking, soft law measures and negative integration. Negative integration has been argued to be especially characteristic for Social Europe; a process where national welfare policies are integrated when EU laws oblige Member States to abolish barriers to the constitutive principles of the Community. ${ }^{9}$ A welfare policy constituting such a barrier is, therefore, against the objectives and means of the EU polity and must be reformed, causing negative integration.

As part of a negative integration process, 'social integration' means constrained policy options for the national welfare state more than a positive build-up of a European social polity. ${ }^{10}$ Indeed this asymmetry still exists. ${ }^{11}$

Positive integration by means of political decision-making encounters many obstacles and vetopositions to be overcome before a compromise can be established. First, the Commission has to internally agree to formulate and present a proposal. Second, the Council of Ministers shall negotiate a common position on the ground of unanimity or, increasingly, qualified majority voting between 27 Member States. Third, increasingly the Council has to use the co-decision procedure with the European Parliament, numbering some 737 members, organized into 7 political groups. An initiative developing Social Europe has a long way to go before it emerges as law, and policy processes have tended to be rather cumbersome with many thresholds. In this context of

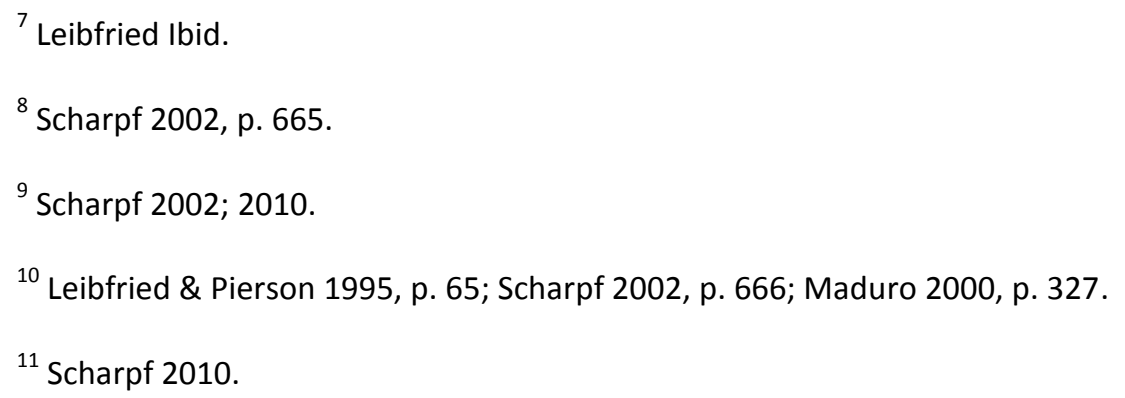


cumbersome decision-making, the policy-making process tends to produce outputs where many compromises are contained in the written text, ambiguously phrased and open to interpretations. Other means to compromises are by inserting an exemption or opt-out in secondary legislation or Treaty Protocols, thus bringing on board Member States who are likely to veto proposals, in order to establish a common position. As decision-makers in the Council, welfare state representatives often act as reluctant players with skeptic attitudes when social initiatives are on the table. ${ }^{12}$

Despite the reluctance and concerns of politicians, social integration has taken place, even at considerable speed. The CJEU has furthered integration, interpreting the 'law of the land' beyond what national governments could at first accept, but gradually have come to terms with. ${ }^{13}$ This dynamic where the Court comes first, opening up for politicians to sometimes codify what the Court has already laid down, appears to be a main integrative logic of social Europe. Such integrative logic comes out historically as well as in more contemporary dynamics.

The Treaty of Rome 1957 had very little social content. One Article was inserted at the request of Italy, in order to support the free movement of workers, setting out that when a worker moved from one Member State to another, s/he had the right to both access the social security schemes of other Member States as well as export already earned social security rights to other Member States. ${ }^{14}$

Another Article was written into the Treaty on the initiative of France, laying down that men and women were entitled to equal pay for equal work. ${ }^{15}$ Despite the rather sparsely social content, both Articles came to spur social integration significantly. Firstly, for migrant workers' social security rights, the CJEU became decisive in expanding the personal and material scope of cross border entitlements. In addition, the Court was crucial in expanding the regulatory meaning of equal pay and went further in linking equal treatment with maternity/parental rights. The politicians gradually came to respond, revising or adopting secondary legislation to codify the case law.

\footnotetext{
${ }^{12}$ Leibfried 2010.

${ }^{13}$ Martinsen 2005; 2009.

${ }^{14}$ Article 51 Treaty establishing the European Economic Community 1957; Holloway 1981; Romero 1993.

${ }^{15}$ Article 119 Treaty establishing the European Economic Community 1957; Cichowski 2001, pp. 116-117; Martinsen 2007, pp. 548-549.
} 
Despite much Member State reticence, the binding norms of EU social regulation have expanded. Falkner has counted 80 binding norms in the three main fields of EU social regulation. ${ }^{16}$ In addition, about 90 amendments and geographical extensions had been adopted to these binding norms and approximately 120 non-binding norms, consisting of soft law measures, recommendations to the Member States etc. ${ }^{17}$ Also health care has come under the scope of EU regulation. Concerning the recently adopted Directive on patient rights, the integrative logic resembles the one described above. The CJEU initated the process of including health care issues within EU law. At first a large majority of Member States were opposed to binding measures but as the case law chipped away at sovereignty and competence in the area of health care they gradually came round to accepting that EU-level legislation was necessary. Thus in co-decision with the European Parliament a first Directive on patient rights in cross border health care has been adopted in March $2011 .{ }^{18}$ Section 3 below will look further into the political response to this process.

\subsection{Social Services of General Interest}

The social services of the welfare state build on the same logic of 'closure' as welfare in general. It can even be argued that their exposure to European integration and the dynamics EU law are especially sensitive as SSGI mirror the institutional core of the modern welfare state; health care, statutory and complementary social security schemes, as well as personal services; social assistance, housing, child care and long term care. ${ }^{19}$

Therefore integration of social services has often been marked by rather fierce political battles and opposition. Politically there have been attempts to rebound social services and shield it against the general forces of integration. The heads of government thus inserted a Protocol 26 on services of general interest as an annex to the Treaty of the Functioning of the European Union. The Protocol

\footnotetext{
${ }^{16}$ Falkner examines what she terms as the main fields EU social regulation as health and safety, other working conditions and equality at the workplace (Falkner 2010, p. 293).

${ }^{17}$ Ibid.

${ }^{18}$ Directive 2011/24/EU of the European Parliament and of the Council of 9 March 2011 on the application of patients' rights in cross-border healthcare, OJ L 88; Gronden et al. 2011; Martinsen 2009.

${ }^{19}$ Ferrera 2009.
} 
speaks of the national concerns with SSGI, and was inserted in the wake of pressure especially from France, the Netherlands and Belgium. ${ }^{20}$ The Protocol emphasizes:

Article 2

The provisions of the Treaties do not affect in any way the competence of Member States to provide, commission and organise non-economic services of general interest.

Although the Treaty sets out explicitly that non-economic social services ${ }^{21}$ are special, and henceforth should be governed by special rules, they are de facto integrated and increasingly part of the supranational regulatory scope as the case-stories of health care and long-term care below details. These two social services, however, also bear witness of considerable political resistance and opposition along the process of integration.

\subsubsection{Health care}

Healthcare constitutes a social service of general interest ${ }^{22}$ and its European integration has been greatly disputed as such. When it was laid down by the CJEU that health care is a service within the meaning of the Treaty, ${ }^{23}$ it was by no means welcomed by the health ministers of the member states. The former German Minister of Health, Seehofer, argued quite impetuously in the wake of the judgments, saying that the member states had to overturn the rulings through a Treaty amendment and that Germany would not comply with the premises of the judgments. ${ }^{24}$ The former Minister found the Decker/Kohll case law 'revolutionary' and argued that if Germany adopted its premises, it would be a long-term threat to the sustainability of the German health system. ${ }^{25} \mathrm{~A}$ Treaty amendment detailing that internal market principles did not apply to health care was called

\footnotetext{
${ }^{20}$ Ibid., p. 227.

${ }^{21}$ For a conceptual discussion of social services of general interests, see the Chapter by Neergaard.

${ }^{22}$ See the Chapter by Baeten and Palm for a detailed account on the preservation of general interests in health care.

${ }^{23}$ In the cases C-120/95 Decker [1998] ECR I-01831 and C-158/96 Kohll [1998] ECR I-01931.

${ }^{24}$ Langer 1999, p. 54.

${ }^{25}$ Der Spiegel 17/98, Fokus from 4 May 1998; Eichenhofer 1999b, p. 114.
} 
for. ${ }^{26}$ As we now know, such a Treaty amendment was never adopted. In the end, Member States did not prioritize the matter sufficiently when negotiating the Treaty of Nice, and the Treaty clarification exempting health care from the internal market was not inserted. ${ }^{27}$

This initial outburst was then later met by significant silence and a long period of no EU initiative. The Member States evidently waited for the Commission to take the lead and point out some kind of direction. In the meantime, the CJEU moved further in its interpretations on patients' rights and cross border health care. In the Geraets-Smits and Peerbooms case, ${ }^{28}$ the Court clarified that internal market principles also apply to hospital care, provided as benefits in kind. In the following case of Müller-Fauré and Van Riet, ${ }^{29}$ the CJEU proceeded by drawing a distinction between hospital care and non-hospital care. For hospital care prior authorization (where the competent national institution has the authority to certify a reimbursable right to cross border treatment) may under certain condition be justified. For non-hospital care it is, however, found to be an unjustified barrier to the free circulation of services. In Müller-Fauré and Van Riet, the Court thus settled that for the wide scope of treatment which can be provided without hospitalization, internal market principles rule.

The first attempt to respond to the Court's rulings came when the Commission, rather unsuccessfully, attempted to integrate the health care area in the proposal for a Directive on services in the internal market. ${ }^{30}$ As a precise reproduction of the Court's decisions, Article 23 of the Directive proposal set out:

1) an internal market for non-hospital care, where the patient has a right to seek treatment in another member state without prior authorization and subsequently have the costs reimbursed by the competent national institution,

\footnotetext{
${ }^{26}$ Martinsen and Falkner 2011.

${ }^{27}$ Martinsen and Falkner ibid.

${ }^{28}$ Case C-157/99 Geraets-Smits and Peerbooms [2001] ECR I-05473.

${ }^{29}$ Case C-385/99 Müller-Fauré v Onderlinge Waarborgmaatschappij OZ Zorgverzekeringen and Van Riet v Onderlinge Waarborgmaatschappij ZAO Zorgverzekeringen [2003] ECR I-04509.

${ }^{30}$ Proposal for a Directive of the European Parliament and of the Council on services in the internal market, COM (2004) 2.
} 
2) a right to hospitalization in another member state, provided that the State of affiliation offers the same treatment, and that authorization has been granted beforehand.

The health ministers, refused to have their policy area regulated as part of a general Directive on services, placed under the responsibility of DG Internal Market. ${ }^{31}$ Article 23, and thus the health care area, was taken out of the Directive. In general, the adopted version of the Services Directive was a much watered down version compared to the original proposal. ${ }^{32}$

Consequently it appeared clear that European health care could not be regulated from an overall internal market perspective, but the case law of the Court still called for political codification and more transparency. In September 2006, DG Health (SANCO) communicated a consultation procedure on health services. One year later, the Commission made its first attempt to present a proposal. DG SANCO announced that the proposal would be presented on 19 December 2007. However, on the very same day the Commission decided to withdraw the proposal. ${ }^{33}$ It remains unclear exactly what triggered the withdrawal, but the political tensions and concerns that the proposal evoked stand out.

Many different actors and organizations worked behind the scene in the run-up to the presentation of the proposal. ${ }^{34}$ Also the Commission was split internally on the proposal. The College of Commissioners disagreed strongly internally on the proposal and its principles. Various cabinets appear to have intervened against the proposal just before it was presented, expressing concerns on the impact on national health systems. ${ }^{35}$ Others were concerned about how the proposal would be received by the public, suggesting that it could cause protests similar to the ones on the Services Directive, which again would be damaging during the process of ratification of the Treaty of Lisbon $2009 .{ }^{36}$ Furthermore, members of the European Parliament intervened in the process. Apparently

\footnotetext{
${ }^{31}$ Szyszczak 2011, pp. 116-117.

${ }^{32}$ Jensen and Nedergaard 2011.

${ }^{33}$ EU Observer, 19 December 2007.

${ }^{34}$ Martinsen 2009.

${ }^{35}$ EU Observer, 7 February 2008.

${ }^{36}$ Martinsen 2009.
} 
key members of the European Socialists (PES) group urged the Commission to withdraw the proposal, arguing that it would have considerable negative consequences for national health care systems. ${ }^{37}$ PES members linked the proposal with the ratification of the Lisbon Treaty, arguing that the timing was badly chosen since the Lisbon Treaty remained to be ratified in several member states. ${ }^{38}$ In the end, the Commission decided not to present the proposal.

However, it did not take more than half a year to ease the pressure on the Commission and to internally agree that a new proposal could be presented. On 2 July 2008, the Commission was successful in proposing the Directive on patient rights. ${ }^{39}$

Also the subsequent negotiation process has been tense and ripe with conflicts on different dimensions of the proposal. The European Parliament has had its difficulties to establish a majority position. The PES group in the Parliament was divided internally on various issues, especially on the fundamental question of the correct legal base for the Directive and the issue of prior authorization. Also the Greens and the united left GUE/NGL were against that the legal base of the Directive was proposed as the internal market Article 114 TFEU and not Article 168 TFEU dealing with public health. ${ }^{40}$ In June 2009, the Commission agreed to meet the Council and Parliamentary concerns to some extent, for example by agreeing to remove long term health care from the regulatory scope of the proposal and to include Article 168 TFEU as part of the legal base. ${ }^{41}$ The Council of Ministers continued its disputes on the content of the proposal. A significant number of Ministers expressed concerns on national sovereignty, and wished to tighten national control in cross border care by means of prior authorization. Especially Southern Europe expressed concerns, and in December 2009 Spain led a blocking minority against the Swedish Presidency compromise text, and the Council thus failed to reach an agreement. However, during 2010 disagreements were eased. The Council reached a common position during the Spanish Presidency and the European Parliament gathered a majority on their second reading January 2011. By March 2011 the Directive

\footnotetext{
${ }^{37}$ Dagens Medicin, 1 February 2008; Politiken, 11 January 2008; Politiken, 19 January 2008.

${ }^{38}$ Politiken, 10 January 2008.

${ }^{39}$ Proposal for a Directive of the European Parliament and of the Council on the application of patients' rights in crossborder health care, COM (2008) 414.

${ }^{40}$ EurActiv, 24 April 2009.

${ }^{41}$ Szyszczak 2011, p. 118.
} 
was adopted by both Institutions. The adopted text differs from the original proposal by the Commission on several aspects. A dual legal basis has been reached. The internal market legal base Article 114 TFEU constitutes the main legal basis, ${ }^{42}$ but Article 168 TFEU (on public health) has also been inserted. Another significant compromise is that prior authorization is accepted as means of national control, but only allowed for:

1) care subject to planning; hospitalization or use of highly specialized or cost-intensive medical infrastructure or equipment;

2) treatments involving a particular risk for the patient or the population;

3) providers raising serious concerns relating to quality and safety (Article 8 (2) of the Directive).

The process which finally reached a compromise on patient rights in cross border care substantiates that it took the representatives of the welfare states in the Council and a considerable part of European Parliamentarians quite some time to accept that health care as a service of general interest falls under the rules of the internal market. The politicians managed to negotiate some exemptions to the general rule of free movement, but the process also substantiates that despite such political reservations, it is now a European binding norm that health care constitutes a service within the meaning of the Treaty, with all its implications. The transposition and practical application of the directive in EU 27 will probably confirm that the reach of Social Europe goes much beyond what the member governments thought they signed to in the Council, March 2011.

\subsubsection{Long term care}

Long term care is another SSGI representing one if the core institutions of the welfare state. As with health care, its integration into EU law and policy has not been lightheartedly received by the Member States, which have long resisted that long term care should be regulated by the EU. The adoption of the patient rights' directive stands out as the recent example of the political

\footnotetext{
${ }^{42}$ The preamble of the Directive lays down that; "Article 114 TFEU is the appropriate legal basis since the majority of the provisions of this Directive aim to improve the functioning of the internal market and the free movement of goods, persons and services" (para 2 of the preamble to Directive 2011/24/EU).
} 
unwillingness to integrate long term care into the EU regulatory scope. ${ }^{43}$ Despite such resistance, long term care is in fact regulated by EU rules, both through soft and hard law mechanisms.

Long term care benefit represents one of those social services which could not easily have been appreciated back when the first building blocks of social Europe was laid down. ${ }^{44}$ The first regulations coordinating the social security rights of migrant workers did not include long term care as part of their material scope. ${ }^{45}$ Although today it is a core part of many European welfare states and a social benefit which receives much attention in times of an ageing European population, long term care took quite some time to be defined as a social service. ${ }^{46}$ Despite the fact that 'reliance on care' has always existed as a social phenomenon, long term care did not figure as an independent or conceptualised social security risk in European or international conventions at the end of the 1970s. ${ }^{47}$ Although by no means being a 'new' social task, it is a social service which, in some member states, has only lately become a part of public welfare, and has been institutionalized beyond the more immediate care provided by the family.

Today, however, long term care is regulated in the EU by the open method of coordination (omc). This soft law measure focuses on the access, quality and sustainability and compares long term care policies in the Member States. The service is provided very diversified within the EU. Long term care may be delivered in long-stay institutions, i.e. residential long term care services, within day centers or within individual homes, i.e. home care service. ${ }^{48}$ Also the service availability differs across Europe. In Scandinavia there is a high reliance on formal care, whereas in for example Southern Europe, long term care has traditionally been provided by family members and formal care remains limited. ${ }^{49}$ Furthermore, the financing of long term care differs considerably. In Germany, Luxembourg and Spain public schemes are financed by social insurance. In the Nordic

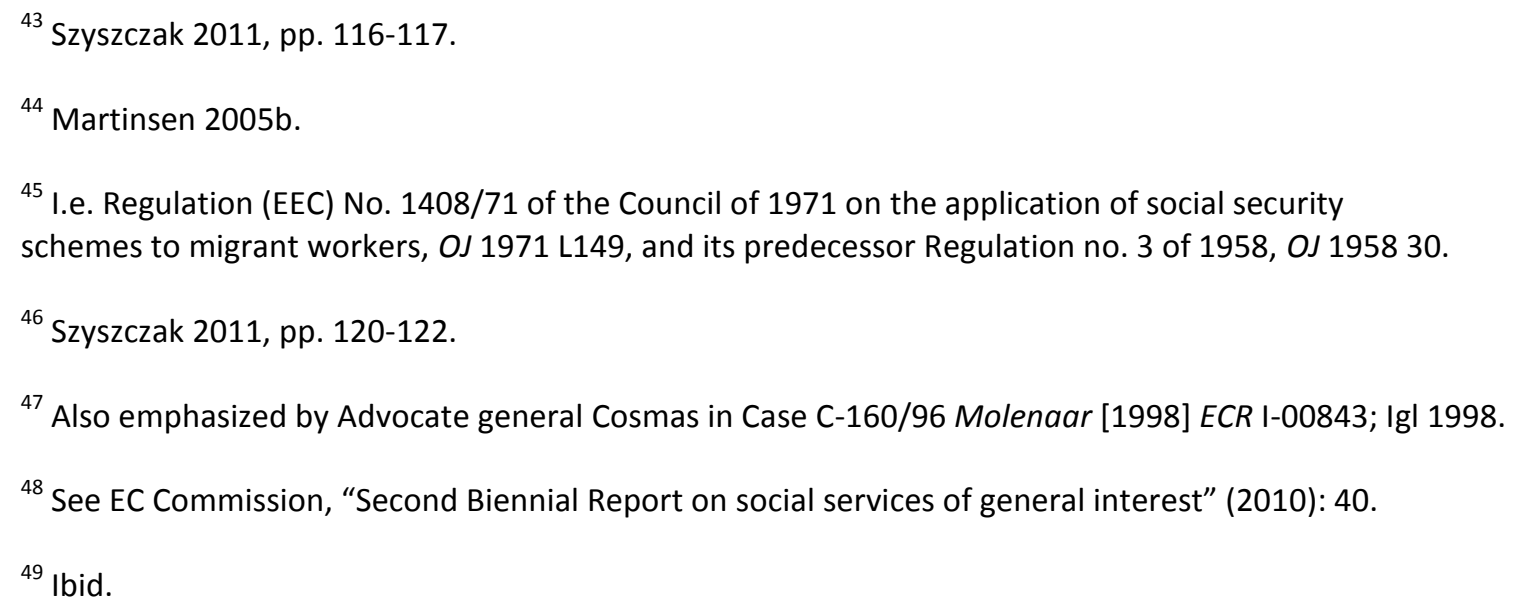


countries and Latvia by means of taxes. UK and Cyprus has means tested schemes. Belgium, France and Greece provide long term care by means of a mixed financing system which combines insurance and taxes. ${ }^{50}$ When addressing sustainability, these financing systems become crucial. In the current time of financial and economic crisis, it can only be expected that the EU will gather further momentum to address the sustainability of long term care schemes, not least with the prospects of an ageing population.

Whereas, the omc is the new approach to place long term care on the European agenda, the social service has, for more than a decade, been regulated by hard law as part of the scheme coordinating social security rights of migrant persons. ${ }^{51}$ As with health care, the inclusion of long term care within the scope of EU law was not initially welcomed by the Member States, and again exemplifies how SSGI are key concerns to the national politicians, preferring to maintain these benefits outside the reach of EU law.

Regulation 883/2004 (former Regulation 1408/71) on the coordination of social security rights applies to all EU citizens as well as their family members. The Regulation is based on a principle of equal treatment, meaning that persons covered by the regulation are equal in terms of the social rights and obligations provided for by the national legislation. Furthermore, the Regulation is based on a principle of exportability according to which one can export/maintain the social security rights that one has achieved in one member state if moving to another Member State. This principle of exportability came to clash with the residence requirements of both the German and Austrian long term care program, and again mirrors a process where the CJEU furthered the meaning and scope of European law beyond what the national politicians thought they had agreed to.

Germany adopted its law on long term care ('Pflegeversicherungsgesetz'), as late as 1995, thereby for the first time recognizing long term care as an independent social risk. ${ }^{52}$ Before the adoption of the care insurance law, long term care was publicly granted as a social assistance benefit, or privately provided and financed. ${ }^{53}$ With its long-term care law, any person in Germany insured

\footnotetext{
${ }^{50}$ European Commission, "Long-term care in the European Union" (2008): 10.

${ }^{51}$ Regulation (EC) No. 883/2004 of the European Parliament and of the Council of 29 April 2004 on the coordination of social security systems, previously Regulation No. 1408/71.

${ }^{52}$ Martinsen 2005b.

${ }^{53}$ Igl \& Stadelmann 1998, p. 37.
} 
against sickness is compulsory insured in the long-term care scheme. The service was financed by contributions from both workers and employers. A social insurance member reliant on care became entitled to care in a nursing home or in his/her own home. If one should desire home care, the law also designated a possibility to choose either care as a benefit in kind, or as a monthly allowance, i.e. 'Pflegegeld' where an individual should purchase the care.

The monthly cash allowance quickly turned out to be the preferred form of home care. From the outset, $80 \%$ of those in home care chose the cash benefit. ${ }^{54}$ However, the German politicians inserted a residence requirement in the law, setting out that the entitlement to the German 'Pflegegeld' was suspended if one took up residence abroad. The law thus demarcated the social provisions within national borders.

Whether the territorial demarcation of the German 'Pflegegeld' contradicted EU law was examined in Molenaar. ${ }^{55}$ The case discussed the right to 'Pflegegeld' of Mr and Mrs Molenaar, a Dutch, German couple, working in Germany but living in France. They were both voluntarily insured against sickness in Germany and were, from January 1995, required to pay care insurance contributions, which they did. However, on application, they were informed by the competent German social security fund that they were not entitled to care insurance benefits due to their French residence.

The CJEU initiated its legal reasoning by referring to previous case law, stating that a benefit was to be regarded as a social security benefit if granted 'on the basis of a legally defined position and provided that it concerns one of the risks expressly listed in Article 4 (1)' of Regulation 1408/71 (para. 20 of the judgment). It added that the list of Article 4 (1), laying down the material scope of the regulation, was exhaustive, meaning that a branch of social security not mentioned in this article was not part of the regulatory scope. Long term care, such as the German 'Pflegeversicherung', was to be regarded as a sickness benefit within the meaning of Article 4 (1) (a) of Regulation 1408. Having in this way included the care allowance within the material scope of 1408/71, the Court continued by examining whether the residence clause of German law could be justified against the Community principle of exportability.

\footnotetext{
${ }^{54}$ Igl 1998, p. 23.

${ }^{55}$ CJEU, Case C-160/96 Manfred Molenaar and Barbara Fath-Molenaar v. Allgemeine Ortskrankenkasse BadenWürttemberg [1998], ECR 1998, I-880.
} 
Article 19 of Regulation 1408/71 made a distinction between benefits in kind and benefits in cash. The competent institution was - and is - obliged to export sickness benefits in cash, but not benefit in kind. ${ }^{56}$ Although a monthly cash allowance, 'Pflegegeld' was defined as a benefit in kind in German law, thus according to German law exempting it from exportability. From the drafting of the law, it appears to have been a deliberate and important consideration to define a de facto 'cash benefit' as a 'benefit in kind'. More specifically, the draft of the 'Pflegeversicherungsgesetz' defended the point of view, setting out that the care allowance constituted a 'benefit in kindsubstitute', a 'Sachleistungssurrogat'. 57 Nevertheless, the CJEU did not accept the national classification, but ruled that the German care allowance was indeed a benefit in cash (para. 36 of the judgment). As a consequence thereof, the overall conclusion was that the residence clause in German law conflicted with the principle of exportability of Regulation 1408/71.

The later case of Jauch $^{58}$ confirmed that long-term care falls within the scope of European law and is exportable in accordance herewith. Jauch concerned a German national, residing in Germany, but who had worked in Austria where he was affiliated to the social security scheme. The Austrian welfare state had, however, denied him long-term care, since he was not a habitual resident in Austria, and since Austria had specified that long-term care was a non-exportable social service. ${ }^{59}$ The Austrian government argued before the ECJ that because the member governments had decided that the benefit was exempted from exportability in accordance with a special rule of nonexportability inserted in Regulation 1408/71, the residence clause of Austrian law did not contravene EU law. The CJEU nevertheless ruled against the Austrian position, laying down that the character of the Austrian care allowance was no different from the German 'Pflegegeld';

\footnotetext{
... while care allowance may possibly have a different legal regime at the national level, it nevertheless remains of the same kind as the German care insurance benefits at issue in Molenaar, and is likewise granted objectively on the basis of a legally defined situation. ${ }^{60}$
}

\footnotetext{
${ }^{56}$ Huster 1999, p. 12.

${ }^{57}$ Zuleeg 1998, p. 172.

${ }^{58}$ CJEU, Case C-215/99 Frederich Jauch v. Pensionsversicherungsanstalt der Arbeiter, [2001] ECR I-1901.

${ }^{59}$ In concrete, the Austrian government had listed the benefit in Annex lla of Regulation 1408/71, an Annex according to which the member governments in the Council of Ministers could insert certain benefits and thus make them nonexportable.

${ }^{60}$ Para 26.
} 
The Molenaar and Jauch cases thus exemplify the attempts of Germany and Austria to exempt their welfare benefits from exportability, and so to speak to construct 'safe havens' in both national and EU law. ${ }^{61}$ The cases also demonstrate that such 'safe havens' may not prove to be lasting firewalls around national social services in the long run. It can be argued that it becomes increasingly difficult to remain insulated on the island or in the 'safe haven', protected from the waves and dynamics of EU law.

\subsection{The Europeanization of welfare}

Health care and long term care both constitute social services of general interest which despite their traditional national boundedness, have been Europeanized. Europeanization has become a prominent analytical concept in European Union studies, defined a national change or processes of change caused by European integration. ${ }^{62}$ When examining the impact of the EU on national politics and law, the Europeanization framework is helpful in setting out how national institutions are changed and why EU induced processes of change may not lead to convergence of domestic schemes. A Europeanization approach details that EU imperatives of change, be they case law from the CJEU, soft law mechanisms or the binding law of a Directive, do not automatically lead to national change. ${ }^{63}$ Between an EU decision and de facto national change there is a long list of intervening variables which can be decisive to the actual EU impact. Judicial policy-making by means of CJEU case law may meet severe national obstacles and national re-interpretations of what the Court actually said, for which reason a significant case may not cause national change in the first place. On the other hand a case, or Directive, may be used strategically by domestic actors to justify why a reform is needed. ${ }^{64}$ At a first glance the implementation of a Directive or Regulation may appear more straightforward and less open to national interpretations. Nevertheless, also the implementation of Council decision-making has proven to leave a significant scope of maneuver to the national executive when the measures are to be transposed into national law and practices.

\footnotetext{
${ }^{61}$ Szyszczak, this volume.

${ }^{62}$ Börzel and Panke 2010.

${ }^{63}$ Schmidt 2002; Radaelli 2003; Caporaso 2007.

${ }^{64}$ Martinsen and Vrangbæk 2009; Kallestrup 2005.
} 
However, when adding the long term perspective, non-compliance with European law is likely to be addressed by the different enforcement mechanisms of the EU; infringement procedures by the Commission, EU law enforced in national courts or preliminary references to the CJEU which review, monitor and eventually sanction a disobedient Member State. Compared to other international organizations, the EU has developed efficient enforcement-management mechanisms, through which detected and pursued, non-compliance is pointed out to be a merely temporal phenomenon. ${ }^{65}$ In sum, the Europeanization approach tells us that we should not expect EU decisions to impact directly on national welfare states, but instead expect EU induced change to be filtered and influenced by national institutions and actors. Compliance studies add to this perspective, detailing that the EU polity has unique instruments of enforcing and managing eventual national non-compliance. ${ }^{66}$ These instruments reduce the national scope of maneuver over time, potentially leading welfare states to gradually change in accordance with their European obligations.

Welfare Europeanization is likely to be reluctant, strongly influenced by national forces, but also checked and balanced by national and supranational enforcement institutions. Europeanization involves at least four steps of change before the output takes a more finalized form. First of all, the EU cause differs. National actors and institutions may decide to simply ignore a soft law measure as there are no formal sanctions linked to such, and obligations vary as to whether the EU cause of change is set out in case law or a Directive. As a second step, transposition allows for governments, administrations and interest organizations to respond to and (re)interpret the EU imperative laid down. Transposition lays down the judicial implementation where EU decisions by means of hard law become national legislation. Thirdly, in the phase of practical application local, regional or central parts of the administration will transcend the law into practice. Even rules may, however, often transcend into uneven practices, depending on administrative capacities, understandings of EU obligations and/or different cultures of compliance at the sublevels of European administration. ${ }^{67}$ Fourthly, the ability to detect and prosecute non-compliance is decisive to the extent the EU polity can render implementation deficits into sufficient compliance with European

\footnotetext{
${ }^{65}$ Tallberg 2002, p. 614.

${ }^{66}$ Tallberg 2002; 2003.

${ }^{67}$ Falkner et al. 2005; Versluis 2007.
} 
obligations. ${ }^{68}$ Evaluation and enforcement at the end of the Europeanization process is thus fundamental to the extent to which a correct output is produced, and objectives and means become de facto impact. Together the four steps of Europeanization demonstrate that a process of EU induced change is far from automatic, but one with high thresholds and significant discretionary scope.

Figure 1 - Processes of welfare Europeanization ${ }^{69}$

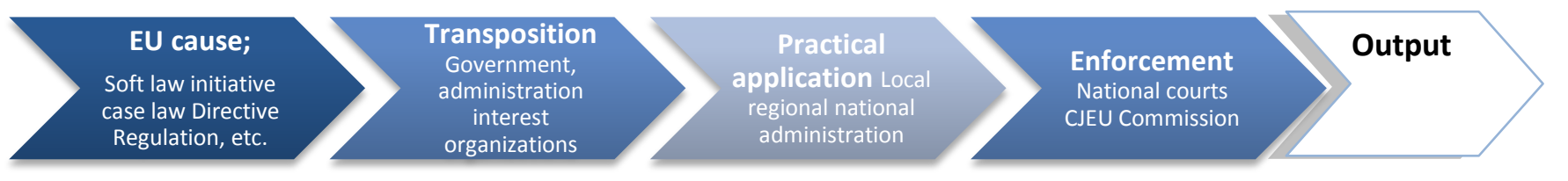

Over the years a significant Europeanization of welfare, and social services of general interest, has taken place. The market building process of the EU implies considerable social integration through the abolition of national barriers to the internal market. ${ }^{70}$ Free movement principles and competition law $^{71}$ are thus fundamental challenges to the traditional logic of 'closure' to the Member States. ${ }^{72}$

\footnotetext{
${ }^{68}$ Tallberg 2002; 2003; Slepcevic 2009.

${ }^{69}$ Treib 2008; Martinsen 2005.

${ }^{70}$ Leibfried \& Pierson 1995, p. 51.

${ }^{71}$ See the Chapter by Neergaard.

${ }^{72}$ Ferrera 2005; 2009.
} 
Furthermore, the principle of non-discrimination prohibits the traditional demarcation of solidarity in the welfare states, where solidarity has been for 'members only', i.e. the citizens of the state. ${ }^{73}$ European integration implies a fundamental challenge to the 'right to bound', meaning 'the right of each national welfare state to autonomously determine who can/must share what with whom'. ${ }^{74}$ Today all European citizens can legitimately access the welfare communities of other Member States. Held against the traditional logic of 'closure', this is indeed a major EU impact on the traditional organization of the welfare state.

Specific policies such as health care and long term care are affected by European integration. The two core institutions of the welfare state can no longer be reserved to the national population, nor can they be preserved within the national borders. Concerning health care, national administrations have lost the upper hand of control. In the future, they will continuously have to justify if a health care service can only be consumed at home. If they refuse a cross border treatment, the European citizen has a right to challenge the refusal by means of judicial redress. Furthermore, national providers' ability to plan will need to take outflows but also a potential inflow of foreign patients into account. In addition, welfare authorities will have to set up national contact centers with the task to inform European patients of national health care supplies, prices and quality. Healthcare packages and services thus need to be comparable across borders. This may set off new dynamics where patients acting as voters demand different standards or types of national treatments. New demands will be voiced and national health care packages will be compared with the supply from other Member States. That changes in supply go hand in hand with changes in demand is already evident in the global growth in medical tourism, where patients travel abroad for health care not available in their home state or cheaper elsewhere. ${ }^{75}$

Regarding long term care, the cases of Molenaar and Jauch, examined above, have already set out how the case law of the Court impacted on the way long term care was organized, and demarcated, in Germany and Austria. The cases demonstrate that although the German and Austrian welfare states deliberately attempted to exempt these social services from the principle of exportability, the 'safe havens' they constructed were not lasting preemptions. The idea to construct a 'benefit in

\footnotetext{
${ }^{73}$ Martinsen 2005.

${ }^{74}$ Ferrera 2009, p. 221.

${ }^{75}$ Szyszczak 2009.
} 
kind-substitute', a 'Sachleistungssurrogat' did not stand the test before the Court. ${ }^{76}$ This demonstrates that in the longer run, the discretionary scope of the national executive on how to organize their social services of general interests is indeed limited. European integration impacts on both the transposition and practical application of social services of general interest. In this way, EU law limits the policy options of the welfare states. When national policies are drafted several ideas are likely to end as non-decisions in order to prevent the impact of EU law. Welfare politicians and bureaucrats are likely to think more than twice on whether to design long term care as a 'benefit in cash', knowing that such service will then be exportable to pensioners who have taken up residence in, for example, Southern Europe or elsewhere beyond national borders.

The administration of social services has in this way been Europeanized, which implies considerable challenges to the national bureaucracy at all administrative levels. From an overall perspective the EU's regulatory competences on social services of general interests are diffuse, differing between direct or indirect hard law measures and non-binding comparisons and recommendations. The individual provision may not fundamentally challenge the administration of welfare, but added together the different bits and pieces of regulation becomes rather deep intervention in the administrative autonomy of the welfare state. The fact that social services fall within the scope of EU law implies that welfare administrations EU-wide have to take the rules into account, when welfare programmes are designed, adopted and administered. Additionally local public authorities have to apply EU rules on state aid and public procurement as well as administer their national laws of social services in accordance with EU law and policy. Thus we find Europeanization at the ultimate end of the administrative order, and the different units of local authorities are unlikely to posses the administrative capacity to take Europe into account in their daily practices. The lack of capacity is substantiated when public authorities notify the Commission that the application of the relevant EU rules to the national policies on social services causes problems. $^{77}$

Local authorities especially have found the application difficult, viewing the different EU rules as an obstacle to organize and finance high quality social services. The Commission has responded that the difficulties are mainly caused by the lack of awareness or misinterpretation of the rules

\footnotetext{
${ }^{76}$ Zuleeg 1998, p. 172.

${ }^{77}$ See the Commission's Second Biennial Report on social services of general interest for this discussion: pp. 70-74. SEC (2010) 1284 final.
} 
rather than the rules themselves. Disregarding such disagreements on reasons, the discussion substantiates that the administrative space of social services is no longer demarcated by national borders or to national communities, but is increasingly Europeanized - at all levels.

\subsection{Conclusions}

Social services of general interests are core institutions of the welfare state, traditionally rooted in the same logic of 'closure' as the welfare state in general. From the outset the constitutive principles of the welfare state and social Europe are contradictions in terms, the former building on a logic of 'closure' and the latter on a logic of 'opening'. ${ }^{78}$ The historical logic of the welfare state can, in part, explain the tension when it meets with Social Europe. Having once been a key means of national integration, it is now gradually obliged to Europeanize. Both social integration and Europeanization has taken place. By means of negative integration, separate Council decisions, judicial policy-making and soft law measures, the EU impacts on the core of the national welfare state. Over time, a Social Europe has been conceived, albeit sometimes in an incoherent and conflicting manner.

This chapter has focused on the tense interaction between the welfare state and Social Europe, looking into the political responses to the integration and Europeanization of SSGI. Despite political reluctance and veto-positions, welfare state representatives have gradually had to accept the reach of EU law. The case studies of health care and long term care demonstrate that although Member Sstates attempt to create 'safe havens', these may not prove to be lasting firewalls against the 'creeping competences' of the European Union. ${ }^{79}$ Over time SSGI have become Europeanized, limiting the scope and policy options for national politicians and national administrations. The administrative space of SSGI is increasingly multi-level, forcing administrators at all levels to take EU rules into account, when welfare programs are designed, adopted and administered. Much has happened since SSGI were islands beyond the reach of European law. ${ }^{80}$

\footnotetext{
${ }^{78}$ Ferrera 2009.

${ }^{79}$ Pollack 2000.

${ }^{80}$ See the Opinion of AGI Tesauro in Ccases C-120/95 Decker and C-158/96 Kohll. Full citation
} 


\section{References}

Börzel T A, Panke D (2010) Europeanization. In: Cini M, Borragán N P-S (eds) European Union Politics. Oxford University Press, Oxford, pp 405-418

Caporaso J (2007) The Three Worlds of Regional Integration Theory. In: Garziano P, Vink M P (eds) Europeanization. New Research Agendas. Palgrave Macmillan, Hampshire, pp 23-35

Cichowski R A (2001) Judicial rulemaking and the institutionalization of European Union sex equality policy. In: Stone Sweet A, Sandholtz W, Fligstein N (eds) The Institutionalization of Europe. Oxford University Press, Oxford, pp 113-137

Eichenhofer E (1999a) Aspekte Europäische Gesundheitspolitik - Der Zugang zu Leistungen der Kranken- und Pflegeversicherung der EU-Bürger - Situation des Koordinierungsrechts und Veränderungsbedarf. In: Igl G (Hrsg.) Europäische Union und gesetzliche Krankenversicherung Status und Entwicklungen der Gesundheitspolitik in der EU. Verlag Chmielorz GmbH, Wiesbaden, pp 45-60

Eichenhofer E (1999b) Das Europäische koordinierende Krankenversicherungsrecht nach den EuGH-Urteilen Kohll und Decker. In: Vierteljahresschrift für Sozialrecht, 2

Eichenhofer E (2000) Die Sozialversicherung - Hinterlassenschaft Bismarcks. In: Eichenhofer E (Hrsg.) Bismarck, die Sozialversicherung und deren Zukunft. Arno Spitz GmbH, Berlin, pp 15-43

European Commission (2008) Long-term Care in the European Union. Office for Official Publications of the European Communities, Luxembourg

European Commission (2010) Commission Staff Working Document. Second Biennial Report on social services of general interests, SEC (2010) 1284 final

Falkner G T, O Hartlapp M, Leiber S (2005) Complying with Europe. EU 
Harmonisation and Soft Law in the Member States. Cambridge University Press, Cambridge

Falkner G (2010) European Union. In: Castles F et al. (eds.) The Oxford Handbook of the Welfare State. Oxford University Press, Oxford, pp 292-306

Ferrera M (2003) European Integration and National Social Citizenship: Changing Boundaries, New Structuring ? Comparative Political Studies, 36(6)

Ferrera M (2005) The Boundaries of Europe. European Integration and the New Spatial Politics of Social Protection. Oxford University Press, Oxford

Ferrera M (2009) The JCMS Annual Lecture: National Welfare States and European Integration: In Search of a 'Virtuous Nesting'. Journal of Common Market Studies, pp 219-233

Giddens A (1994) Beyond Left and Right - the Future of Radical Politics. Polity Press, Cambridge

Gronden J W van de, Szyszczak E, Neergaard U, Krajewski M (eds) (2011) Health Care and EU Law. T.M.C. Asser Press, The Hague

Holloway J (1981) Social Policy Harmonisation in the European Community. Gower Publishing Company Limited, Westmead

Huster S (1999) Grundfragen der Exportpflicht im europäischen Sozialrecht. Neue Zeitschrift für Sozialrecht, heft 1, pp 10-17

Igl G (1998) Pflegeversicherung als neuer Gegenstand sozialrechtlicher Regulierung. In: Sieveking K (Hrsg.) Soziale Sicherung bei Pflegebedürftigkeit in der Europäischen Union. Nomos Verlagsgesellschaft, Baden-Baden, pp 19-37

Igl G, Stadelmann F (1998) Die Pflegeversicherung in Deutschland. In: Sieveking K (Hrsg.) Soziale Sicherung bei Pflegebedürftigkeit in der Europäischen Union. Nomos Verlagsgesellschaft, BadenBaden, pp 37-51 
Jensen M D, Nedergaard P (2011) From ,Frankenstein“ to ,toothless vampire‘? Explaining the watering down of the Services Directive. European Journal of Public Policy, on-line first, pp 1-19 Kallestrup M (2005) Europæisering af Nationalstaten. DJØFs Forlag, København Langer R (1999) Grenzüberschreitende Behandlungsleistungen - Reformbedarf für die Verordnung 1408/71. Neue Zeitschrift für Sozialrecht, 11, pp 537-542

Leibfried S, Pierson P (1995) Semisovereign Welfare States: Social Policy in a Multitiered Europe. In: Leibfried S, Pierson P (eds.) European Social Policy - Between Fragmentation and Integration. The Brookings Institution, Washington, D.C., pp 43-77

Leibfried S (2010) Social Policy: Left to the Judges and the Markets?. In: Wallace H, Pollack M A Young A R (eds) Policy-making in the European Union. Oxford University Press, Oxford, pp 253283

Maduro M P (2000) Europe’s Social Self: „The Sickness unto Death. In: Shaw J. (ed.) Social Law and Policy in an Evolving European Union. Hart Publishing, Oxford, pp 325-349

Martinsen D S (2005) The Europeanization of Welfare - The Domestic Impact of Intra-European Social Security. Journal of Common Market Studies, 43:5, pp 1027-1054

Martinsen DS (2005b) Social security regulation in the EU : the de-territorialization of welfare? In: De Búrca G (ed.) EU law and the welfare state. In search of solidarity. Oxford University Press, Oxford, pp 89-111

Martinsen D S, Vrangbæk K (2008) The Europeanization of Health Care Governance: Implementing the market imperatives of Europe. Public Administration, 86 (1), pp 169-184

Martinsen D S (2009) Conflict and Conflict Management in the Cross-border Provision of Healthcare Services. West European Politics, 32(4), pp 792-809 
Martinsen D S, Falkner G (2011) Social Policy: Problem Solving Gaps, Partial Exits and CourtDecision Traps. In: Falkner G (ed.) The EU's Decision Traps. Comparing Policies. Oxford University Press, Oxford, pp 128-145

Radaelli C M (2003) The Europeanization of Public Policy. In: Featherstone K and Radaelli C (eds) The Politics of Europeanization. Oxford University Press, Oxford, pp 27-57

Romero F (1993) Migration as an issue in European interdependence and integration: the case of Italy. In: Milward A et al. (eds.) The Frontier of National Sovereignty - History and Theory 1945 1992. Routledge, London, pp 33-59

Scharpf F W (2002) The European Social Model: Coping with the Challenges of Diversity. Journal of Common Market Studies, 40(4), pp 645-670

Scharpf F W (2010) The asymmetry of European integration, or why the EU cannot be a 'social market economy. Socio-Economic Review, 8, pp 211-250

Schmidt V A (2002) Europeanization and the Mechanisms of Economic Policy Adjustment. Journal of European Public Policy, 9(6), pp 894-912

Slepcevic R (2009) The judicial enforcement of EU law through national courts: possibilities and limits. Journal of European Public Policy, 16(3), pp 378-394

Szyszczak E (2009) Modernising Healthcare: Pilgrimage for the Holy Grail?. In: Krajewsji M, Neergaard U, van de Gronden JW (eds) The Changing Legal Framework for Services of General Interest in Europe. Asser Press, The Hague

Tallberg J (2002) Paths to Compliance: Enforcement, Management and the European Union. International Organization, 56(3), pp 609-643

Tallberg J (2003) European governance and supranational institutions: making states comply. Routledge, London, New York 
Treib O (2008) Implementing and complying with EU governance outputs. Living Reviews in European Governance, 3(5), p 1-30

Versluis E (2007) Even rules, uneven practices: Opening the 'black box' of EU law in action. West European Politics, 30(1), pp 50-67

Von Maydell B (1999) Auf dem Wege zu einem gemeinsamen Markt für Gesundheitsleistungen in der Europäischen Gemeinschaft. Vierteljahresschrift für Sozialrecht, 1, 3-19

Zuleeg M. (1998) Die Einwirkung des Europäischen Gemeinschaftsrechts auf die deutsche Pflegeversicherung. In: Sieveking K (ed.) Soziale Sicherung bei Pflegebedürftigkeit in der Europäischen Union. Nomos Verlagsgesellschaft, Baden-Baden, pp 159-179 